\title{
Characterization of severe Plasmodium falciparum malaria patients in an Angolan general ICU
}

\author{
Esmael Tomás ${ }^{1 *}$, E Filipe ${ }^{1}$, E Viegas ${ }^{1}$, A Sá ${ }^{2}$, F Silva ${ }^{1}$, L Antunes ${ }^{1}$, E Lafuente $^{2}$ \\ From Parasite to Prevention: Advances in the understanding of malaria \\ Edinburgh, UK. 20-22 October 2010
}

\section{Introduction}

Malaria is the most important human parasitic disease, causing an estimated 500 million cases and more than 1 million deaths annually. Plasmodium falciparum is responsible for the most serious form of the disease with a significant mortality rate.

\section{Objective}

To characterize severe Plasmodium falciparum malaria patterns in patients admitted to an Angolan general ICU.

\section{Methods}

A retrospective study based on medical records of adult patients with severe Plasmodium falciparum malaria admitted between January 2006 and December 2008 at an Angolan University-affiliated teaching hospital. We collected data on demographics, malaria-related immunity status, clinical presentation, WHO malaria severity criteria, laboratory findings and outcome. Continuous data were analyzed with Students t-test. A $P$ of less than 0.05 was regarded to be significant.

\section{Results}

Out of 114 patients admitted with diagnosis of malaria, we enrolled 56 patients. Forty-four (79\%) were males. The mean age was $43.0 \pm 12.9$. Twenty-eight (50\%) were nonimmune and only two were adherent to chemoprophylaxis, but reported taking it incorrectly. Fifty-two percent were admitted during the second trimester. The mean APACHE II was $15.4 \pm 8.7$ with a mean predicted dead rate of $25.9 \%$. The mean SOFA on admission was $7.6 \pm 3.6$. Fever $(82 \%)$ followed by headache $(41 \%)$ and gastrointestinal symptoms (36\%) were the most common symptoms on admission and jaundice (61 \%) the most common sign. The mean duration of symptoms prior to presentation at

${ }^{1}$ Clínica Sagrada Esperança, ICU, Angola

Full list of author information is available at the end of the article the ED was $6.1 \pm 4.3$ days. Malaria diagnosis was confirmed within 24 hours of admission to our hospital In all the cases. Twelve patients presented 2 or more WHO severity major criteria. Forty-one patients were treated with quinine and twelve with artemether. Nineteen patients (34\%) required ventilatory support, twenty (36\%) intermittent hemodialysis and twelve (21\%) vasopressor support. The mean ICU length of stay was $5.5 \pm 3.8$ days. The 2 -day mortality rate and total ICU mortality rate recorded was $10.7 \%$ and $37.5 \%$, respectively.

\section{Conclusions}

In this review, the criteria usually pointed as predictors of a poor outcome on sepsis cases were found to have statistical significance in malaria-related deaths.

\section{Table 1 Characteristics of survival and nonsurvival} groups

\begin{tabular}{|c|c|c|c|}
\hline Survival $(n=35)$ & $\begin{array}{c}\text { Non-survival } \\
(n=21)\end{array}$ & $p$ & \\
\hline Age, Mean \pm SD & $43.7 \pm 12.5$ & $42.0 \pm 14.0$ & 0.66 \\
\hline APACHE 11, Mean \pm SD & $12.1 \pm 6.2$ & $21.0 \pm 9.4$ & $<0.0001$ \\
\hline $\begin{array}{l}\text { SOFA on admission (total), } \\
\text { Mean } \pm \text { SD }\end{array}$ & $6.5 \pm 3.3$ & $9.6 \pm 3.5$ & 0.0013 \\
\hline Non-Immune, n(\%) & $18(51.4)$ & $10(47.6)$ & 0.79 \\
\hline $\begin{array}{l}\text { Two or more WHO severity } \\
\text { criteria, } \mathrm{n}(\%)\end{array}$ & $1(0.3)$ & $11(52.4)$ & $<0.0001$ \\
\hline $\begin{array}{l}\text { Platelets }\left(\times 103 / \mathrm{mm}^{3}\right) \\
\text { Mean } \pm \text { SD }\end{array}$ & $85.8 \pm 86.3$ & $65.3 \pm 57.3$ & 0.35 \\
\hline Bilirubin $(\mathrm{mg} / \mathrm{dl})$, Mean \pm SD & $4.8 \pm 4.7$ & $6.9 \pm 7.2$ & 0.08 \\
\hline $\begin{array}{l}\text { Creatinine }(\mathrm{mg} / \mathrm{dl}) \text {, Mean } \pm \\
\text { SD }\end{array}$ & $3.6 \pm 3.15$ & $3.9 \pm 2.6$ & 0.67 \\
\hline $\begin{array}{l}\text { C-reactive protein }(\mathrm{mg} / \mathrm{l}) \text {, } \\
\text { Mean } \pm \mathrm{SD}\end{array}$ & $118.0 \pm 87.5$ & $140.0 \pm 103.0$ & 0.45 \\
\hline $\begin{array}{l}\text { Arterial lactates }(\mathrm{mmol} / \mathrm{l}) \text {, } \\
\text { Mean } \pm \mathrm{SD}\end{array}$ & $3.4 \pm 2.89$ & $5.4 \pm 4.6$ & 0.019 \\
\hline $\begin{array}{l}\text { Parasitemia ( } \times 10^{3} \text { parasites/ } \\
\left.\mathrm{mm}^{3}\right) \text {, Mean } \pm \text { SD }\end{array}$ & $30.5 \pm 28.8$ & $27.8 \pm 36.7$ & 0.73 \\
\hline
\end{tabular}




\section{Author details}

${ }^{1}$ Clínica Sagrada Esperança, ICU, Angola. ${ }^{2}$ Centro Hospitalar Tamega Sousa, ICU, Portugal.

\section{Published: 20 October 2010}

\section{References}

1. WHO: Trans RSOC Trop Med Hyg 2000

2. Mphahlele, et al: Polskie archiwum medycyny wewnetrznej 2008.

doi:10.1186/1475-2875-9-S2-P52

Cite this article as: Tomás et al:: Characterization of severe Plasmodium falciparum malaria patients in an Angolan general ICU. Malaria Journal 2010 9(Suppl 2):P52.

Submit your next manuscript to BioMed Central and take full advantage of:

- Convenient online submission

- Thorough peer review

- No space constraints or color figure charges

- Immediate publication on acceptance

- Inclusion in PubMed, CAS, Scopus and Google Scholar

- Research which is freely available for redistribution

Submit your manuscript at www.biomedcentral.com/submit
C Biomed Central 